\title{
Effects of Field and Greenhouse Solarization on Soil Microbiota and Weed Seeds in the Northeast USA
}

\author{
Sonja K. Birthisel ${ }^{1, *}$, Grace A. Smith ${ }^{2}$, Gavriela M. Mallory ${ }^{3}$, Jianjun Hao ${ }^{1}$ and Eric R. Gallandt ${ }^{1}$ \\ ${ }^{1}$ Ecology and Environmental Sciences Program, University of Maine, Orono, ME, USA \\ 2 Molecular and Biomedical Sciences Department, University of Maine, Orono, ME, USA \\ ${ }^{3}$ Biology Department, Swarthmore College, Swarthmore, PA, USA \\ * Corresponding author: E-Mail: sonja.birthisel@maine.edu; Tel.: +1 207-228-3601; Fax: +1 207-581-2999
}

Submitted: 10 October 2018 | In revised form: 23 February 2019 | Accepted: 3 October 2019 |

Published: 30 December 2019

\begin{abstract}
Soil solarization using clear plastic is a promising weed management strategy for organic farms in the Northeast USA. Based on grower concerns that the practice might negatively affect beneficial soil microbiota, we conducted experiments to measure the effects of 2 and 4 weeks of solarization in a field and a closed greenhouse. Soil microbial communities were assayed by dilution plating on semi-selective agar media. Populations of general bacteria, general fungi, bacilli, and florescent pseudomonads were unaffected by field solarization, but fluorescent pseudomonads were reduced following greenhouse solarization. At plastic removal, soil biological activity was reduced non-significantly in the field and by $45 \%$ in the greenhouse. Soil biological activity fluctuated following field solarization, being significantly suppressed at 5 but not 14 days after plastic removal. In the greenhouse, biological activity remained suppressed up to 28 days after plastic removal. Solarization increased available nitrogen in the field and greenhouse. Four weeks of solarization reduced viability of buried weed seeds by $64 \%$ in the field and $98 \%$ in the greenhouse, indicating that the practice can cause substantial weed seed mortality. Maximum soil temperatures, measured at $10 \mathrm{~cm}$ depth under solarization, were $44^{\circ} \mathrm{C}$ in the field and $50^{\circ} \mathrm{C}$ in the greenhouse; temperatures were theoretically sufficient for the reduction of some soil borne pathogens. A subsequent experiment measured the effects of solarization and tarping (black plastic) on soil biological activity. During mulching, biological activity was unaffected by treatment, but 14 days after plastic removal, biological activity was reduced in the solarized treatment as compared with the control. Overall, these results suggest that solarization can deplete the weed seedbank. Although soil biological activity was reduced by solarization, it may bounce back after a period. Greenhouse solarization achieved higher temperatures and was more lethal to weed seeds and some microbiota than field solarization.
\end{abstract}

Keywords: Bacillus; Chenopodium album; $\mathrm{CO}_{2}$ evolution; Digitaria sanguinalis; florescent pseudomonads; Sinapis arvensis; soil heating; tarping; weed management; weed seedbank 


\section{Introduction}

Soil solarization is the practice of controlling pests by covering irrigated soil with clear plastic tarps, using solar energy to heat soils to lethal temperatures [1]. Solarization has long been known to kill weeds [2,3] and soilborne pathogens $[4,5]$ in warm, sunny climates. It was thought to be inconsistently effective in cooler regions [6], but recent work by our group demonstrated that two weeks of spring solarization in the humid continental climate of Maine, USA prepared an excellent stale seedbed (Birthisel and Gallandt, this issue). These promising results prompted questions from organic farmers in our region about mechanisms and best practices for solarization, as well as concerns about impacts on soil microbiota, nutrient cycling, and soil health. The experiments described herein sought to build on existing knowledge [7] and address a lack of necessary [8] region-specific data on these topics.

The mechanisms through which solarization causes weed suppression in our region have yet to be fully elucidated. Solarization may cause thermal inactivation [9] or fatal germination of some species, while enforcing dormancy in others [10]. The temperature thresholds required for thermal seed death may be altered by environmental factors including soil moisture [11] and soil organic content [12]. From a seedbank management standpoint, direct mortality of seeds or seedlings is a more desirable outcome than forcing seed dormancy [13].

Although solarization is considered a 'mild' soil treatment in comparison to other disinfestation techniques including steaming [14], it nonetheless affects the soil ecosystem beyond the control of target pests. Solarization often increases dissolved organic matter $[15,16]$ and plant available nutrients including inorganic nitrogen [16-18]. Gelsomino \& Cacco [19] report that solarization in Italy altered microbial community composition during treatment. Scopa et al. found that soil respiration rates decreased non-significantly during field solarization [20], but significantly under solarization within a greenhouse [21]. It is well established that survival or rapid recolonization of the rhizosphere by beneficial mesophilic microbiota following solarization can induce soil suppressiveness against pathogens [22], which can positively impact crop growth. We are aware of no prior studies exploring the effect of solarization in the Northeast USA on beneficial soil microbiota.

Variations on solarization that are of interest to organic farmers in our region include greenhouse solarization and tarping. Conducting solarization within a greenhouse [23] or covering fields with multiple plastic layers [24] typically results in higher soil temperatures than single-layer solarization, and can improve pest control efficacy $[25,26]$. Tarping, also known as occultation, utilizes black plastic or heavy-gauge silage tarps to block sunlight from reaching the soil for several weeks prior to planting [27]. Black plastic results in lower soil temperatures and less consistently effective weed control than solarization in warmer regions [2,28]. The impacts of greenhouse solarization and tarping on soil microbiota have not been previously studied in the Northeast USA.

We conducted paired experiments in a field and a greenhouse to measure impacts of two solarization durations ( 2 weeks and 4 weeks) on soil microbiota, assessed via plate counts and soil biological activity, and on weed seeds and soil available nitrogen. In a separate field experiment, we compared the effects of 4 weeks of solarization and tarping on soil biological activity at three soil depths. The hypotheses guiding these experiments were as follows:

1. Solarization will reduce all including beneficial soil microbiota during treatment, but the beneficial microbes will return to control levels following treatment;

2. Soil available nitrogen will increase as a result of solarization;

3. Solarization will cause mortality of buried weed seeds;

4. Greenhouse solarization will achieve higher temperatures and be more lethal to microbiota and weed seeds than field solarization;

5. Tarping will be less lethal to microbiota than field solarization; and

6 . The impacts of field solarization and tarping on soil microbiota will decrease with increasing depth from the soil surface.

\section{Materials and Methods}

\subsection{Field and Greenhouse Solarization}

\subsubsection{Site Description}

Paired experiments were conducted during June to August of 2016 in an open field (hereafter FIELD experiment) and an adjacent greenhouse (GHOUSE experiment). The site $\left(44^{\circ} 54^{\prime} \mathrm{N} 68^{\circ} 39^{\prime} \mathrm{W}\right.$; Figure A1) had been in sod for decades before construction of a $33 \mathrm{~m}$ by $8 \mathrm{~m}$ double layered 6 mil $(0.15 \mathrm{~mm})$ polyethylene high-tunnel, in-field greenhouse in 2012; the open field was added to production in 2014. Prior to these experiments, the field was left fallow in 2015, and amended with compost in April of 2016. The greenhouse had been planted to organic salad greens in the fall of 2015 and spring of 2016. Soils were Peru-Tunbridge association. The field had $17.9 \%$ organic matter, $6.6 \mathrm{pH}$, and N-P-K of $21 \mathrm{ppm}-406 \mathrm{~kg} \mathrm{ha}^{-1}-2660 \mathrm{~kg} \mathrm{ha}^{-1}$; the greenhouse $9.2 \%$ organic matter, $6.2 \mathrm{pH}$, and N-P-K of 90 ppm-97 kg ha-1-1644 kg ha ${ }^{-1}$ (June 2016 soil tests, sampled to a depth of $10 \mathrm{~cm}$ ). The high organic matter at these sites, an artifact of past management, likely introduced a 'biosolarization' effect [12] into these experiments, potentially increasing the efficacy of solarization in comparison to what would be expected at lower organic matter levels.

Air temperatures over the course of these experiments averaged $19.7^{\circ} \mathrm{C}$ with a total rainfall of $20 \mathrm{~cm}$ [29] (Appendix A2). The 30-year historical averages (calculated over the period 1981-2010) for temperature and rainfall for the months June through August were $19^{\circ} \mathrm{C}$ and $26 \mathrm{~cm}$, respectively [30]. 


\subsubsection{Experimental Design}

The FIELD and GHOUSE experiments were each arranged as a randomized complete block design with four replicates of three treatments: solarized for 2 weeks, solarized for 4 weeks, and unsolarized control. Plots were $1.5 \mathrm{~m}$ by $3.0 \mathrm{~m}$ with $0.3 \mathrm{~m}$ paths between plots. Soils were rototilled to 15 cm depth 1 to 2 days prior to the experiment start date, 22 June 2016. To begin the experiment, all plots were irrigated to approximate field capacity, and solarization treatments covered with previously used 6 mil $(0.15 \mathrm{~mm})$ polyethylene greenhouse plastic, the edges of which were secured by burial. Previously used plastic was chosen in order to reflect likely grower practices in our region (Birthisel and Gallandt, this issue). Plastic was removed with care to minimize soil disturbance on 6 July for 2-week treatments, and on 20 July for 4-week treatments. After plastic removal (hereafter termination), plots were left undisturbed for subsequent observation and measurement.

\subsubsection{Field Data Collection}

Soil temperatures were logged hourly during treatment using iButton temperature loggers (Maxim Integrated, San Jose, CA). One logger per plot was placed in a sealed 5 $\mathrm{cm}$ by $5 \mathrm{~cm} 4 \mathrm{mil}(0.10 \mathrm{~mm})$ plastic bag and buried at 10 $\mathrm{cm}$ soil depth. Soil moisture was measured and averaged across three locations per plot using a Delta-T soil moisture meter ( $\mathrm{HH} 2$ version 4.0, Delta-T Devices Ltd, Cambridge, England) on every date that samples were collected.

Bulk soil samples, later sub-divided for measurement of microbial colony forming units (CFU), soil biological activity, and available nitrogen, were collected prior to irrigation and plastic application on 22 June 2016, directly after plastic termination (removal), and five or six days following termination (2-week treatments: 11 July; 4-week treatments: 25 July). Additional samples were collected for soil biological activity measurement at 14 days after termination of 4 -week treatments ( 2 August) and 28 days after termination of 4-week treatments in the GHOUSE experiment only (16 August). Baseline samples collected at the start of experiments consisted of 10 soil cores per block. Subsequent samples, each consisting of 5 soil cores, were taken at the plot level. Soil cores were collected to $10 \mathrm{~cm}$ depth using a sterilized 7.6 cm diameter bulb planter (Yard Butler IBPL-6 Bulb and Garden Planter, Lewis Tools, Poway, CA), placed in plastic bags, mixed well, and refrigerated prior to processing.

To test for treatment effects on weed seed viability, seed bags were constructed by sewing a total of 30 weed seeds into polypropylene tea bags (dimensions $6.5 \mathrm{~cm}$ by $8 \mathrm{~cm}$; mesh gauge $\leq 200 \mu \mathrm{m}$ ) consisting of 10 seeds each of the following endemic species: Sinapis arvensis L., Digitaria sanguinalis (L.) Scop., and Chenopodium album L. Seeds were purchased in 2016 from Azlin Seed Service (Leland, MS, USA, 38756). One seed bag was buried at $1 \mathrm{~cm}$ depth near the center of each control and 4-week treatment plot prior to plastic installation. Seed bags were exhumed at termination of 4-week treatments and refrigerated prior to processing.

\subsubsection{Laboratory Analyses}

The impact of solarization on soil microbial communities was measured by dilution plating and enumeration of colony forming units (CFU) following the methods of Meng et al. [31]. Four selective media were used: 1/10 strength tryptic soy agar $+100 \mathrm{mg} \mathrm{L}^{-1}$ cyclohexamide $\left(\mathrm{TSA}_{+1 / 10}\right)$ to isolate general bacteria; Rose Bengal Chloramphenicol (RBC) to isolate general fungi; Gould's S1 [32] to isolate fluorescent pseudomonads, and full strength tryptic soy agar amended with $100 \mathrm{mg} \mathrm{L}^{-1}$ cyclohexamide (TSA ${ }_{+}$) with samples heated to $80^{\circ} \mathrm{C}$ for $30 \mathrm{~min}$ to isolate Bacillus spp. Suspensions of $10 \mathrm{~g}$ well-mixed soil in $90 \mathrm{~mL}$ sterilized phosphate-buffered saline solution were shaken for $20 \mathrm{~min}$ at $300 \mathrm{rpm}$ and serially diluted. Two replicate plates of each media were inoculated with $100 \mu \mathrm{L}$ of diluted sample and incubated at room temperature prior to enumeration: 2 days for general bacteria, fluorescent pseudomonads, and Bacillus spp.; 3 days for general fungi. Plate counts were standardized using the following equation:

$$
\mathrm{CFU} \mathrm{g}{ }^{-1} \text { soil }=\mathrm{N}^{*} \mathrm{D} \mathrm{V} \mathrm{V}^{-1}
$$

where $\mathrm{N}$ is number of colonies plate ${ }^{-1}, \mathrm{D}$ is the dilution factor $\left(10^{1}\right.$ to $\left.10^{5}\right)$, and $\mathrm{V}$ is the volume of culture plated $(100 \mu \mathrm{L})$. Standardized counts from replicate plates were averaged.

Soil biological activity was measured through $\mathrm{CO}_{2}$ evolution assays following the methods of Franzlubbers [33]. Soil samples were dried for 3 days at $55^{\circ} \mathrm{C}$, passed through a $4 \mathrm{~mm}$ sieve, and $100 \mathrm{~g}$ or $50 \mathrm{~g}$ soil placed in a beaker and re-wetted to approximated $50 \%$ water-filled pore space. Re-wetted samples were incubated at $25^{\circ} \mathrm{C}$ for 3 days in $0.95 \mathrm{~L}$ jars alongside two open $25 \mathrm{~mL}$ vials: one containing $10 \mathrm{~mL} 1 \mathrm{M} \mathrm{NaOH}$ (889573, Carolina Biological Supply Company, Burlington, $\mathrm{NC}$ ) to trap evolved $\mathrm{CO}_{2}$, the other containing $10 \mathrm{~mL} \mathrm{H} \mathrm{H}_{2} \mathrm{O}$ for humidity. A blank was included with each set of samples. Following incubation, vials of $\mathrm{NaOH}$ were mixed with $\leq 5.25 \mathrm{~mL} 1 \mathrm{M} \mathrm{BaCl}_{2}$ (LC116052, LabChem, Zelienople, PA) to form a precipitate, and 2 to 3 drops phenolphthalein color indicator added. $\mathrm{NaOH}$ solutions were titrated against $1 \mathrm{M} \mathrm{HCl}$ (867843, Carolina Biological Supply, Burlington, NC) until color changed from pink to clear. Soil biological activity was calculated as:

$$
\mathrm{CO}_{2}-\mathrm{C} \mathrm{mg} \mathrm{kg}^{-1} \text { soil }=\left(\mathrm{mL}_{[\text {blank }]}-\mathrm{mL}_{[\text {sample }]}\right) * \mathrm{~N}^{*} \mathrm{M} \mathrm{S}^{-1}
$$

where $\mathrm{N}$ is the normality of acid $\left(1 \mathrm{~mol} \mathrm{~L}^{-1}\right), \mathrm{M}$ is the mass conversion from $\mathrm{cmol}_{c}$ to $\mathrm{g} \mathrm{C} \mathrm{(6000),} \mathrm{and} S$ is the soil weight $(\mathrm{kg})$.

In preparation for available soil nitrogen $\left(\mathrm{NO}_{3}^{-}\right.$and $\left.\mathrm{NH}_{4}^{+}\right)$ testing, samples were dried at room temperature, passed through a $2 \mathrm{~mm}$ sieve, and $3.0 \mathrm{~g}$ shaken with $30 \mathrm{~mL} 2.0$ $\mathrm{M} \mathrm{KCl} \mathrm{(P217-10,} \mathrm{Fisher} \mathrm{Scientific,} \mathrm{Fair} \mathrm{Lawn,} \mathrm{NJ)} \mathrm{at} 320$ rpm for $1 \mathrm{~h}$, centrifuged at $2700 \times \mathrm{g}$ for $20 \mathrm{~min}$, and the supernatent passed through $2 \mu \mathrm{m}$ filter paper (Ahlstrom 642, Ahlstrom Corporation, Helsinki, Finland). Samples were frozen prior to transferral to the University of Maine Analytical Lab and Maine Soil Testing Service for measurement of $\mathrm{NO}_{3}^{-}$and $\mathrm{NH}_{4}^{+}$. 
Weed seed viability was measured using tetrazolium assays. Within $48 \mathrm{~h}$ of exhumation, seeds were removed from mesh bags, placed on moistened filter paper (P8, Fisher Scientific, Pittsburgh, PA, USA, 15275) in $100 \mathrm{~mm} \times$ $15 \mathrm{~mm}$ Petri dishes and left to imbibe at room temperature overnight. Germinated and decayed seeds were removed and counted as viable and non-viable, respectively. Remaining seeds were placed on dry filter paper, bisected longitudinally, and stained with 1 to 2 drops triphenyl tetrazolium chloride solution (1\% by weight: T8877-10G, Sigma Life Science, St. Louis, MO, USA, 63013). Seeds were incubated for $24 \mathrm{~h}$, after which seeds stained pink were counted as viable, and seeds remaining unstained were counted as non-viable. Percent seed viability was calculated as:

$$
\% \text { viability }=\left(\mathrm{V}_{r} \mathrm{~T}_{r}^{-1}\right) * 100
$$

where $\mathrm{V}_{r}$ is the number of viable seeds recovered and $\mathrm{T}_{r}$ is the total number of seeds recovered after burial.

\subsubsection{Statistical Analyses}

Data were analyzed with analysis of variance (ANOVA), analysis of covariance (ANCOVA), and multivariate analysis of variance (MANOVA) [34,35] in $\mathrm{R}$ [36]. Response variables were $\log _{10}+1$ or square root transformed as appropriate to improve normality and homogeneity of variances. The chosen significance level was $\alpha=0.05$. Multivariate analyses were performed using functions from 'Biostats R' [37], and packages energy [38] and vegan [39]. The multcomp package [40] was used for multiple comparisons, and pgirmess [41] for permutation tests. The gdata package [42] was used for some aspects of data cleaning. Separate models were fit for FIELD and GHOUSE experiments in all cases. Statistical assumptions were met unless otherwise noted.

To test for solarization impacts on soil microbial communities, MANOVA models were fit with average $\mathrm{CFU} \mathrm{g^{-1 }}$ soil of the four microbial taxa (general bacteria, general fungi, Bacilli, fluorescent pseudomonads) as response variables, and explanatory variables: treatment, duration (numeric), and treatment by duration interaction. Separate models were fit for measurements at termination and 5 days post termination. Missing data ( $8 \%$ of observations) were replaced with median values. Neither model adhered to the assumption of multivariate normality; Pillai's trace was therefore chosen as the test statistic because it is considered robust to modest violations of MANOVA assumptions [35].

To test whether solarization affected soil biological activity, ANCOVA models were fit for termination and termination +5 day measurements, respectively, with soil biological activity $\left(\mathrm{CO}_{2}-\mathrm{C} \mathrm{mg} \mathrm{kg}{ }^{-1}\right.$ soil) as the response, and explanatory variables: treatment, duration, and their interaction. ANOVA models were fit for termination +14 and termination +28 day data.

To test for solarization effects on available nitrogen, MANOVA models were fit using available nitrogen $\left(\mathrm{NO}_{3}^{-}\right.$, $\mathrm{NH}_{4}^{+}$) as responses, with explanatory variables: treatment, duration, and their interaction. Separate models were fit for termination and termination +5 day measurements. Missing data ( $1 \%$ of observations) were replaced with median values. Pillai's trace was used as the test statistic due to modest violations of MANOVA assumptions [35].

To test whether four weeks of solarization resulted in direct mortality of buried weed seeds, ANOVA models were fit with percent seed viability as the response, and explanatory factors: treatment, seed species, and their interaction. This GHOUSE model violated the assumption of normality, so a permutation test (permutations $=1000$ ) was used to obtain simulated P-values $[34,41]$

\subsection{Comparing Solarization to Tarping}

To compare the effects of solarization and tarping on soil biological activity, measurements were taken during a 2016 experiment (hereafter TARP), which is described in full in Birthisel and Gallandt (this issue). This TARP experiment was conducted at the University of Maine Rogers Farm $\left(44^{\circ} 55^{\prime} \mathrm{N}, 68^{\circ} 41^{\prime} \mathrm{W}\right)$ on Pushaw-Boothbay complex soils [43] with $6.2 \mathrm{pH}$ and $3.7 \%$ organic matter (2014 soil test). Soil samples for biological activity analysis were collected prior to application of clear and black plastic mulches (14 July 2016), on the day plastic was removed after four weeks of treatment (9 August), and 14 days after plastic termination (25 Aug). Prior to sample collection, soil was gently firmed by stepping on a $23 \mathrm{~cm}$ by $23 \mathrm{~cm}$ board placed on the soil surface. Samples were collected from three depth strata $(0-2 \mathrm{~cm}, 2-5 \mathrm{~cm}$, and $5-10 \mathrm{~cm})$ using a series of $7.5 \mathrm{~cm}$ diameter cylinders inserted into the soil. To obtain sufficient soil volume for analysis, three samples from each depth strata were collected per plot and bulked. Samples were refrigerated prior to processing. Laboratory measurement of soil biological activity followed the methods described in section 2.1.4. above [33]. To test for treatment and soil depth effects, ANCOVA models were fit for termination and termination + 14 day data, respectively, with soil biological activity as the response and explanatory variables: treatment (control, solarization, tarping), sample depth (numeric: $2,5,10)$, and their interaction. Means were separated by Fisher's protected LSD.

\section{Results}

\subsection{Field and Greenhouse Solarization}

Maximum temperatures were greater in solarized treatments than non-treated controls, and greater in the GHOUSE experiment as compared with the FIELD experiment (Table 1). Accumulated time at temperatures greater than $35^{\circ} \mathrm{C}$ was zero in controls for both experiments, increased under FIELD solarization, and more than doubled under GHOUSE solarization as compared with FIELD solarization (Table 1). Baseline mean \pm SD soil moisture values were $22 \pm 5$ in the FIELD experiment and $20 \pm 8$ in GHOUSE. Conditions were quite dry in the GHOUSE soils by the end of treatment (Table 1). 
Table 1. Mean \pm SD maximum and average temperatures, exposure time to temperatures above $35^{\circ} \mathrm{C}$, and volumetric soil moisture in FIELD and GHOUSE experiments.

\begin{tabular}{|c|c|c|c|c|c|c|c|c|}
\hline \multirow{2}{*}{ Experiment } & \multirow{2}{*}{ Treatment } & \multirow{2}{*}{$\begin{array}{c}\text { Duration } \\
\text { (weeks) }\end{array}$} & \multicolumn{2}{|c|}{ Soil temperature $\left({ }^{\circ} \mathbf{C}\right)$} & \multicolumn{3}{|c|}{ Exposure time (h) } & \multirow{2}{*}{$\begin{array}{c}\text { Soil moisture } \\
\text { (\%vol) }\end{array}$} \\
\hline & & & maximum & maximum & $36-40^{\circ} \mathrm{C}$ & $41-45^{\circ} \mathrm{C}$ & $>45^{\circ} \mathrm{C}$ & \\
\hline \multirow[t]{4}{*}{ FIELD } & control & 2 & $31 \pm 1^{y}$ & $22 \pm 1^{y}$ & $0^{y}$ & $0^{y}$ & $0^{y}$ & $11 \pm 1$ \\
\hline & & 4 & $32 \pm 2^{y}$ & $23 \pm 1^{y}$ & $0^{y}$ & $0^{y}$ & $0^{y}$ & $11 \pm 3$ \\
\hline & solarization & 2 & $39 \pm 3$ & $28 \pm 1$ & $28 \pm 22$ & $4 \pm 4$ & 0 & $14 \pm 8$ \\
\hline & & 4 & $38 \pm 5$ & $27 \pm 3$ & $39 \pm 31$ & $10 \pm 20$ & 0 & $12 \pm 3$ \\
\hline \multirow{4}{*}{ GHOUSE } & control & 2 & $33^{z}$ & $27^{z}$ & $0^{z}$ & $0^{z}$ & $0^{z}$ & $1 \pm 1$ \\
\hline & & 4 & $35^{z}$ & $27^{z}$ & $0^{z}$ & $0^{z}$ & $0^{z}$ & $1 \pm 1$ \\
\hline & solarization & 2 & $44 \pm 1$ & $34 \pm 0$ & $74 \pm 9$ & $48 \pm 5$ & 0 & $3 \pm 1$ \\
\hline & & 4 & $46 \pm 3$ & $34 \pm 1$ & $123 \pm 20$ & $87 \pm 16$ & $19 \pm 28$ & $2 \pm 1$ \\
\hline
\end{tabular}

Temperatures were measured at $10 \mathrm{~cm}$ soil depth and means calculated across four replicates unless otherwise noted: ${ }^{y}$ data

from 3 replicates; ${ }^{z}$ data from one replicate. Soil moisture was measured in three locations per plot at plastic termination.

Baseline counts of mean \pm SD CFU g ${ }^{-1}$ soil for the FIELD experiment were general bacteria $6.8 \pm 0.2$, general fungi $5.8 \pm 0.2$, bacilli $5.9 \pm 0.1$, and fluorescent pseudomonads $5.6 \pm 0.1$ (data reported on a $\log _{10}+1$ transformed scale). Solarization treatment did not greatly impact FIELD microbial populations at either the time of plastic termination or 5 days post termination (Table 2). Duration of treatment was a significant term in the 5-daypost-termination model (Table 2). Baseline GHOUSE populations (CFU g ${ }^{-1}$ soil) were general bacteria $7.3 \pm 0.4$, general fungi $5.7 \pm 0.1$, bacilli $6.5 \pm 0.1$, and florescent pseudomonads $5.0 \pm 0.1$ (data reported on a $\log _{10}+1$ transformed scale). Treatment was a significant factor affecting the microbial community at termination and 5 days post termination (Table 3). Specifically, fluorescent pseudomonad populations were reduced in solarized plots as compared with non-treated controls; other taxa were weakly or inconsistently impacted (Table 3). Duration of treatment was a significant term in both models, though an overarching pattern was not apparent (Table 3).

Table 2. Mean \pm SD microbial colony counts from FIELD experiment and corresponding MANOVA results.

\begin{tabular}{|c|c|c|c|c|c|c|c|c|}
\hline \multirow{3}{*}{$\begin{array}{l}\text { Colony counts } \\
\text { (CFU g } \text { goil) }^{-1} \text { soil }\end{array}$} & \multicolumn{4}{|c|}{ Termination } & \multicolumn{4}{|c|}{ Termination +5 days } \\
\hline & \multicolumn{2}{|c|}{ control } & \multicolumn{2}{|c|}{ solarization } & \multicolumn{2}{|c|}{ control } & \multicolumn{2}{|c|}{ solarization } \\
\hline & 2 week & 4 week & 2 week & 4 week & 2 week & 4 week & 2 week & 4 week \\
\hline general bacteria & $7.3 \pm 0.5$ & $7.7 \pm 0.5$ & $7.6 \pm 0.6$ & $7.6 \pm 0.4$ & $7.2 \pm 0.2$ & $7.4 \pm 0.4$ & $7.5 \pm 0.7$ & $7.5 \pm 0.2$ \\
\hline general fungi & $5.1 \pm 0.4$ & $4.8 \pm 0.9$ & $5.1 \pm 0.5$ & $5.3 \pm 0.8$ & $5.7 \pm 0.1$ & $5.1 \pm 0.3$ & $6.0 \pm 0.2$ & $5.7 \pm 0.3$ \\
\hline bacilli & $6.4 \pm 0.4$ & $6.7 \pm 0.2$ & $6.5 \pm 0.4$ & $6.6 \pm 0.4$ & $\mathrm{nd}^{y}$ & $6.1 \pm 0.3$ & nd & $6.5 \pm 0.4$ \\
\hline f. pseudomonads & $5.4 \pm 0.3$ & $4.4 \pm 0.2$ & $4.8 \pm 0.6$ & $4.7 \pm 0.8$ & $5.5 \pm 0.3$ & $4.8 \pm 0.5$ & $5.5 \pm 0.5$ & $5.0 \pm 1.1$ \\
\hline MANOVA & $\mathrm{df}$ & Pillai's & $\mathrm{F}$ & $p$ & $\mathrm{df}$ & Pillai's & $F$ & $p$ \\
\hline treatment & 1 & 0.05 & 0.11 & 0.98 & 1 & 0.61 & 3.53 & 0.05 \\
\hline duration & 1 & 0.36 & 1.24 & 0.36 & 1 & 0.75 & 6.66 & $<0.01^{*}$ \\
\hline$t \times d$ & 1 & 0.29 & 0.93 & 0.49 & 1 & 0.33 & & 0.41 \\
\hline residuals & 12 & & & & 12 & & & \\
\hline
\end{tabular}

Models were constructed to test the effects of solarization treatment and duration on soil microbiota for the day treatments were terminated, and 5 days after termination. ${ }^{y} \mathrm{nd}=$ no data. $P$-values significant at an $\alpha=0.05$ level are denoted with an asterisk ( ${ }^{*}$ ).

Table 3. Mean \pm SD microbial colony counts from GHOUSE experiment and corresponding MANOVA results.

\begin{tabular}{|c|c|c|c|c|c|c|c|c|}
\hline \multirow{3}{*}{$\begin{array}{l}\text { Colony counts } \\
\text { (CFU g }^{-1} \text { soil) }\end{array}$} & \multicolumn{4}{|c|}{ Termination } & \multicolumn{4}{|c|}{ Termination +5 days } \\
\hline & \multicolumn{2}{|c|}{ control } & \multicolumn{2}{|c|}{ solarization } & \multicolumn{2}{|c|}{ control } & \multicolumn{2}{|c|}{ solarization } \\
\hline & 2 week & 4 week & 2 week & 4 week & 2 week & 4 week & 2 week & 4 week \\
\hline general bacteria & $7.8 \pm 0.4$ & $7.1 \pm 0.2$ & $7.2 \pm 0.4$ & $7.2 \pm 0.7$ & $7.5 \pm 0.3$ & $8.0 \pm 0.6$ & $7.4 \pm 0.3$ & $7.8 \pm 0.7$ \\
\hline general fungi & $5.6 \pm 0.3$ & $5.9 \pm 0.5$ & $4.3 \pm 0.4$ & $5.7 \pm 0.6$ & $5.5 \pm 0.4$ & $5.6 \pm 0.2$ & $5.2 \pm 0.6$ & $5.7 \pm 0.6$ \\
\hline bacilli & $7.0 \pm 0.2$ & $6.6 \pm 0.6$ & $6.9 \pm 0.1$ & $6.5 \pm 0.4$ & $\mathrm{nd}^{y}$ & $6.5 \pm 0.3$ & nd & $6.5 \pm 0.2$ \\
\hline f. pseudomonads & $4.9 \pm 0.6$ & $0.9 \pm 1.8$ & $4.1 \pm 0.8$ & $0.0 \pm 0.0$ & $5.0 \pm 0.3$ & $4.4 \pm 0.8$ & $1.0 \pm 2.0$ & $1.3 \pm 1.6$ \\
\hline MANOVA & $\mathrm{df}$ & Pillai's & $\mathrm{F}$ & $p$ & $\mathrm{df}$ & Pillai's & $\mathrm{F}$ & $p$ \\
\hline treatment & 1 & 0.69 & 4.96 & $0.02^{*}$ & 1 & 0.87 & 15.09 & $<0.01^{*}$ \\
\hline duration & 1 & 0.94 & 35.87 & $<0.01^{*}$ & 1 & 0.63 & 3.84 & $0.04^{*}$ \\
\hline$t \times d$ & 1 & 0.56 & 2.84 & 0.09 & 1 & 0.14 & 0.37 & 0.83 \\
\hline residuals & 12 & & & & 12 & & & \\
\hline
\end{tabular}

Models were constructed to test the effects of solarization treatment and duration on soil microbiota for the day treatments were terminated, and 5 days after termination. ${ }^{y} \mathrm{nd}=$ no data. $P$-values significant at an $\alpha=0.05$ level are denoted with an asterisk ( ${ }^{*}$ ). 
Baseline soil biological activity $\left(\mathrm{CO}_{2}-\mathrm{C}\right)$ mean \pm SEM values in FIELD and GHOUSE experiments were $185 \pm 3 \mathrm{mg} \mathrm{kg}^{-1}$ soil and $153 \pm 10 \mathrm{mg} \mathrm{kg}^{-1}$ soil, respectively. In the FIELD experiment, solarization did not significantly reduce biological activity during treatment (Figure $1 \mathrm{~A}$; $F=4.90, p=0.05)$. Subsequently, there was a significant reduction at 5 days (Figure $1 \mathrm{~B} ; \mathrm{F}=7.13, p=0.02$ ) but not 14 days after plastic removal (Figure $1 \mathrm{C} ; \mathrm{F}=2.24, p=0.18$ ). In the GHOUSE experiment, solarization reduced soil biological activity during treatment (Figure $1 \mathrm{D} ; \mathrm{F}=20.86, p<0.01$ ), and differences persisted through 28 days of subsequent measurement (Figure $1 \mathrm{E}-\mathrm{G}$ ). Duration of solarization and treatment by duration interaction were not significant terms $(p \geq 0.05)$. $\mathrm{R}^{2}$ values underpinning FIELD models were: termination $=0.36$, 5 days post termination $=0.49$, and 14 days post termination $=0.27 ; R^{2}$ values for GHOUSE models were termination $=$ $0.68,5$ days post termination $=0.71,14$ days post termination
$=0.82$, and 28 days post termination $=0.87$.

In the FIELD experiment, baseline soil available nitrate and ammonium mean \pm SEM values were $2.2 \pm 1.0 \mathrm{NO}_{3}^{-}-\mathrm{N} \mathrm{mg} \mathrm{L}^{-1}$ soil and $1.3 \pm 0.1 \mathrm{NH}_{4}^{+}-\mathrm{N} \mathrm{mg} \mathrm{L}^{-1}$ soil, respectively. Available nitrogen was elevated in solarized treatments as compared with controls at termination and 5 days thereafter (Figure 2). Duration of treatment and treatment by duration interaction were not significant terms $(p \geq 0.05)$.

Weed seed viability was reduced under solarization in both FIELD and GHOUSE experiments (Figure 3). There was a significant species effect in the FIELD model, but no significant treatment by species interaction (Figure $3 \mathrm{~A}$; Appendix Table A1). All weed species were greatly reduced following GHOUSE solarization (Figure $3 \mathrm{~B}$ ) with no significant species or interaction effects (Appendix Table A1). $R^{2}$ values for these models were 0.47 in FIELD and 0.87 in GHOUSE.

\section{FIELD}
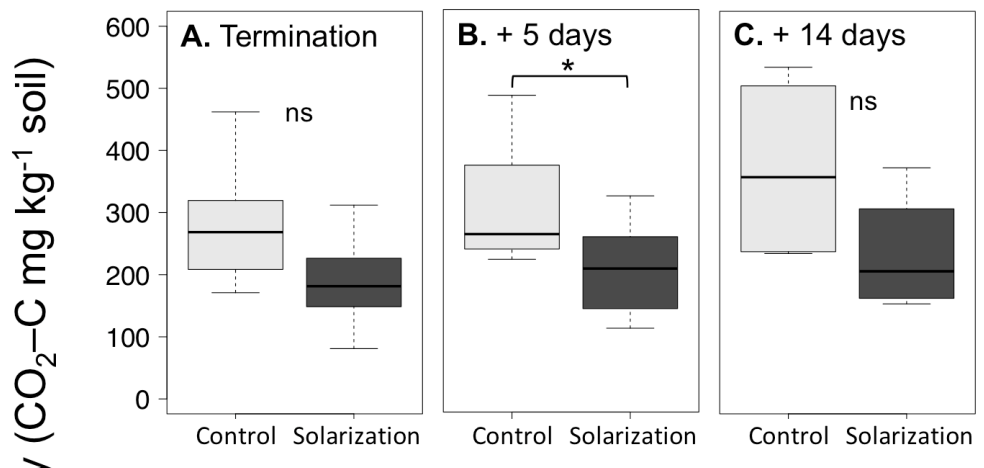

\section{GHOUSE}
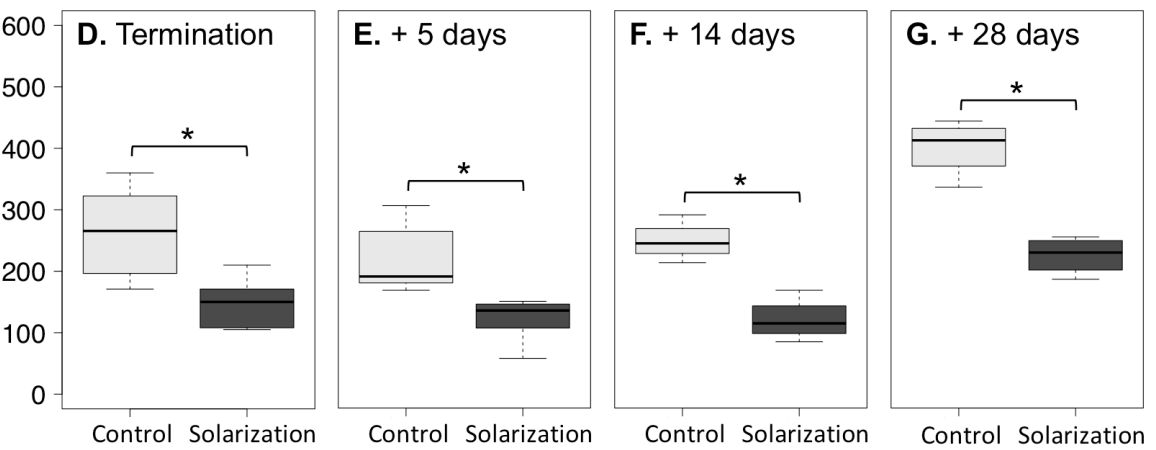

Figure 1. Soil biological activity in the FIELD experiment at (A) plastic termination, $(B)$ termination +5 days, and $(C)$ termination +14 days, and in the GHOUSE experiment at (D) termination, (E) termination + 5 days, $(F) 14$ days post termination, and $(\mathrm{G}) 28$ days post termination. Data are shown pooled across treatment durations. Asterisks $\left({ }^{*}\right)$ indicate significant difference at $\alpha=0.05$, and ns indicates no significant difference. 


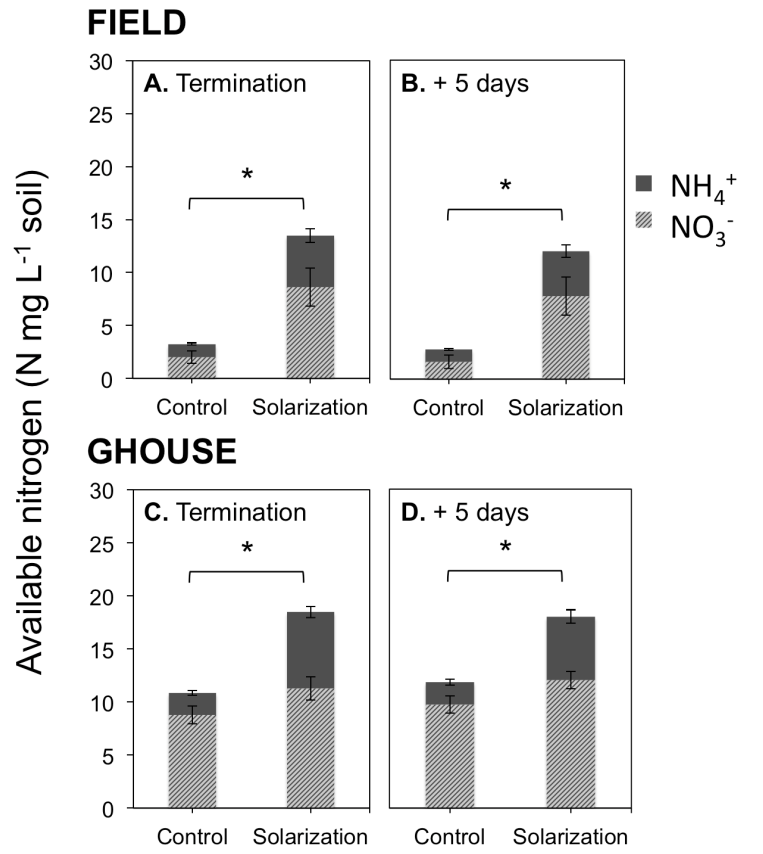

Figure 2. Mean \pm SEM available nitrogen in the FIELD experiment $(A)$ at plastic termination and $(B)$ five days after termination, and in the GHOUSE experiment $(\mathrm{C})$ at termination and (D) five days after termination. Data are shown pooled across treatment durations. Asterisks $\left({ }^{*}\right)$ denote statistically significant treatment effects at $\alpha=0.05$.

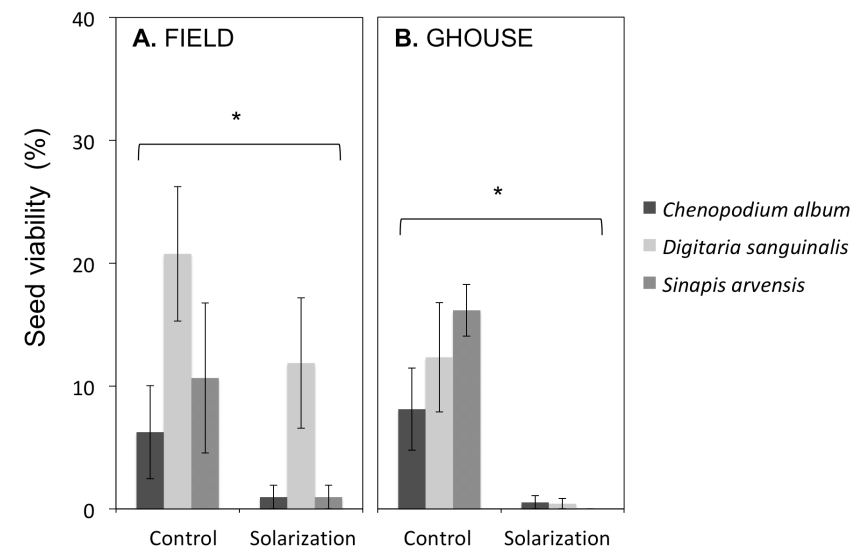

Figure 3. Mean \pm SEM seed viability of three weed species after four weeks of burial in non-treated control and solarization treatments in (A) FIELD and (B) GHOUSE experiments. Asterisks $\left({ }^{*}\right)$ denote statistically significant treatment effects at $\alpha=0.05$.

\subsection{Comparing Solarization to Tarping}

In the TARP experiment, soil biological activity was evaluated at three soil depths during and after four weeks of field solarization and tarping treatment. Soil depth and treatment by depth interactions were not significant $(p \geq 0.05)$. Treatment did not impact soil biological activity at plastic termination (Figure $4 \mathrm{~A}$ ), but 14 days thereafter, soil biological activity was reduced in the solarized treatment as compared with the non-treated control (Figure $4 \mathrm{~B}$ ). $\mathrm{R}^{2}$ values were 0.21 and 0.61 for termination and 14-day-post-termination models, respectively.

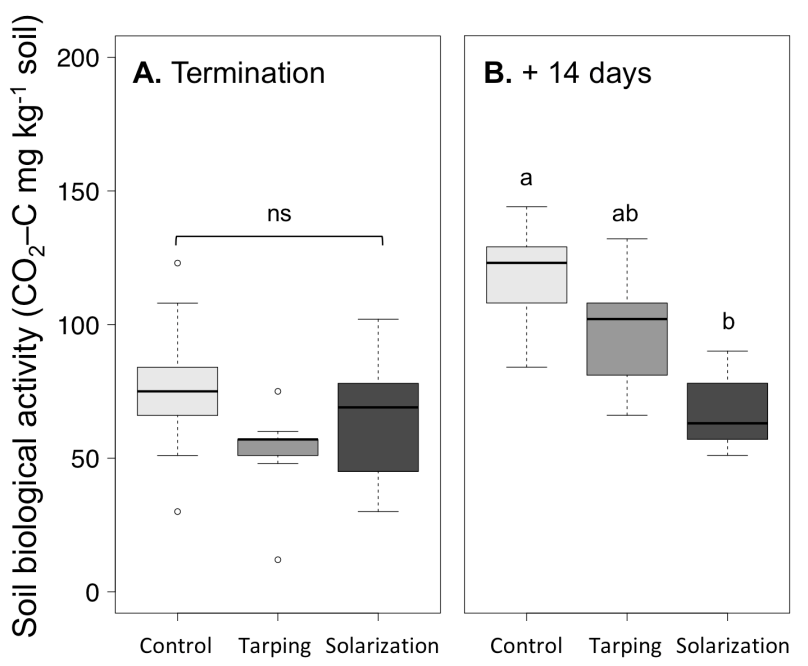

Figure 4. Soil biological activity in the TARP experiment (A) at plastic termination, and (B) 14 days after plastic termination in non-treated control, tarping, and solarization treatments. Data are shown pooled over treatment depths. Connecting letters reflect means separated by Fisher's protected LSD at $\alpha=0.05$; ns indicates no significant difference.

\section{Discussion}

\subsection{Field and Greenhouse Solarization}

Soil solarization is an established method of pest control $[3,5]$ that can create an effective stale seedbed in the Northeast USA (Birthisel and Gallandt, this issue); however, its effects on soil health in our humid continental climate have not been previously reported. Microbial communities are important to agroecosystem function [44], and many organic farmers prioritize the maintenance of soil health [45]; thus questions of solarization's non-target impacts are of relevance to growers.

Based on the assumption that most soil microbiota at our study site would be adapted to ambient temperatures, we hypothesized that overall, beneficial microbe populations would be reduced during treatment, but would quickly re-colonize from lower soil layers thereafter (Hypothesis 1) [22]. The data indicated that solarization in our FIELD experiment had transient effects on soil biological activity (Figure $1 \mathrm{~A}-\mathrm{C}$ ), and population of the four taxa we measured were not significantly impacted (Table 2). This suggests that many species present in our soils, including generally beneficial rhizosphere bacteria of the Bacillus and Pseudomonas genera [46-48], were resilient to field solarization. In the case of bacilli, this is unsurprising given their known ability to form spores [49] that allow survival at temperatures 
exceeding $80^{\circ} \mathrm{C}$. Though our findings offer weak support for Hypothesis 1, they are nonetheless consistent with past studies. Scopa et al. found that soil biological activity was reduced, but not significantly, during field solarization in southern Italy [20], while numerous studies have concluded based on plate counts that field solarization did not permanently harm beneficial microbiota [22].

Available nitrogen $\left(\mathrm{NO}_{3}^{-}\right.$and $\mathrm{NH}_{4}^{+}$) was elevated during and after solarization (Figure 2), consistent with our expectation (Hypothesis 2) and the results of past studies [16-18]. Mechanisms of available nitrogen increase may include increased mineralization [50] or breakdown of microbial cells. Gamliel and Katan [22] note that the growth of crop plants is often stimulated following solarization, due at least partially to increased soil nutrient availability. Thus, solarization in the Northeast USA could provide additional benefits beyond weed control, and might be well suited as a stale seedbed treatment prior to sowing heavy-feeding crops.

Weed seed viability overall was greatly reduced by solarization (Figure 3), supporting Hypothesis 3 . Under the conditions in our FIELD experiment (Table 1), Digitaria sanguinalis appeared to suffer less mortality than other species (Figure $3 \mathrm{~A}$ ), though this was not reflected statistically. The time and temperature requirements for weed seed thermal death are known to vary by species [9] due to traits such as seed coat hardness $[11,51]$. Weed seed mortality may have been elevated in this study due to high soil organic matter. The $17.9 \%$ organic matter measured in our FIELD experiment, though still within the range found on operating organic farms in our region [52], is quite high. Incorporation of organic amendments prior to solarization, termed biosolarization, is known to decrease the time needed for thermal inactivation of weed seeds [53] and can lead to enhanced control of soilborne pathogens as well $[12,54,55]$. Though the practice is promising, more work evaluating the impact of biosolarization on beneficial soil microbiota is advised; Kanaan et al. found that soil biological activity was reduced during and for four weeks following solarization integrated with compost application [56].

We expected greenhouse solarization to result in higher soil temperatures and greater mortality of microbes and weed seeds than field solarization (Hypothesis 4). Consistent with this hypothesis, soil biological activity (Figure 1 D-G), microbial populations (Table 3), and weed seed mortality (Figure $3 \mathrm{~B}$ ) were reduced by greater magnitudes or with more consistency by solarization in our GHOUSE as compared with our FIELD experiment. Congruent with these results, greenhouse solarization reduced biological activity during treatment in a study by Scopa et al. [21]. The reduction in fluorescent pseudomonads we measured during greenhouse solarization (Table 3 ) is consistent with previously reported temperature sensitivity of this taxon [57] (Table 1). However, fluorescent pseudomonads have been shown to quickly re-colonized after treatment: Gamliel and Katan [58] reported that fluorescent pseudomonads were reduced during solarization, but two days after sowing tomatoes in vitro, rhizosphere populations were higher in solarized soils than controls. It is possible that dry soil conditions (Table 1) or an absence of vegetation (Laffley A, unpublished data) in our GHOUSE experiment slowed expected recolonization. Viability of buried weed seeds was reduced by $98 \%$ in our GHOUSE experiment, with all three species well controlled (Figure $3 \mathrm{~B}$ ), demonstrating that greenhouse solarization in the Northeast USA can result in substantial weed seedbank depletion at shallow depth.

\subsection{Comparing Solarization to Tarping}

Results of our TARP experiment offered little support for the hypothesis that tarping is less lethal to microbiota than field solarization (Hypothesis 5). Despite higher soil temperatures under solarization as compared with tarping (Birthisel and Gallandt, this issue), soil biological activity was not affected by treatment at the time of plastic removal (Figure $4 \mathrm{~A}$ ), and a trend toward less biological activity following solarization as compared with tarping was not significant (Figure 4 B). Overall, this provided little support for Hypothesis 5 , suggesting rather that solarization may not pose an increased risk to soil microbes as compared with tarping in our system. The hypothesis that impacts of treatment on soil biological activity would decrease with increasing soil depth (Hypothesis 6) was also unsupported. Differences by depth might have been detected if we had included soil strata deeper than $10 \mathrm{~cm}$ [59].

We were surprised that soil biological activity showed a delayed negative response to solarization, evident in the significant difference between solarized and non-treated control plots measured 14 days after plastic termination (Figure $4 \mathrm{~B}$ ). Following the logic of Hypothesis 1, we had expected the opposite temporal trend: that biological activity would be reduced during treatment, but would return to control levels rapidly thereafter. Though we do not have a mechanistic explanation for this result, potential contributing factors include changes in microbial community composition [19,55] or the soil chemical environment [15-18] during and after solarization.

\subsection{Potential for Plant Pathogen Control}

Solarization can contribute to effective soilborne pathogen control in warmer climates [5], but we are aware of no studies examining its efficacy in our region.

We compared temperature maxima and accumulated thermal time measured in our FIELD and GHOUSE experiments (Table 1) to published thermotolerance thresholds of common soilborne pathogens that impact vegetable and horticultural crops in Maine (Table 4). Solarization would theoretically reduce populations of nearly half of these pathogens under conditions measured in our FIELD experiment, and over two-thirds of species under GHOUSE conditions. Only Botrytis cinerea, the fungus causing noble rot or gray mold in horticultural crops including grape, was expected to be stimulated by solarization [60]. This brief review is limited to the theoretical effects of temperature on 
regionally important vegetable and horticultural pathogens, indication that field and, especially, greenhouse solarization and does not account for other environmental aspects in- have the potential to contribute to plant pathogen reduction fluencing pathogen survival. Nonetheless, this provides in the Northeast USA.

Table 4. Expected responses of some plant pathogens common in the Northeast USA to temperature conditions obtained in our FIELD and GHOUSE experiments.

\begin{tabular}{llccc}
\hline \multirow{2}{*}{ Pathogen species } & Common name & \multicolumn{2}{c}{ Expected response } & \multirow{2}{*}{ Source } \\
\cline { 2 - 3 } & & FIELD & GHOUSE & \\
\hline Alternaria cucumerina & Alternaria leaf blight & + & + & \\
Alternaria solani & early blight & 0 & + & {$[61]^{z}$} \\
Botrytis cinerea & noble rot & - & - & {$[62]^{y}$} \\
Fusarium solani f. sp. cucurbitae & Fusarium rot of cucurbits & 0 & + & {$\left[^{y}\right.$} \\
Pectobacterium atrosepticum & blackleg & + & + & {$[62]^{y}$} \\
Pectobacterium carotovorum & soft rot & 0 & 0 & {$[63]^{z}$} \\
Phytophthora erythroseptica & pink rot & 0 & + & {$[64]^{z}$} \\
Phytophthora infestans & late blight & + & + & {$[65]^{y}$} \\
Plasmodiophora brassicae & club foot & 0 & 0 & {$[66]^{z}$} \\
Rhizoctonia & belly rot & 0 & + & {$[67]^{y}$} \\
Sclerotinia sclerotiorum & white mold & + & + & {$[65]^{y}$} \\
Verticillium dahliae & Verticillium wilt \#1 & 0 & + & {$[68]^{y}$} \\
Verticillium albo-atrum & Verticillium wilt \#2 & + & + & {$[69]^{y}$} \\
\hline
\end{tabular}

\footnotetext{
Expected pathogen responses are categorized as reduced in number due to treatment (+), not affected by treatment $(0)$ or stimulated by treatment (-). All cited studies measured pathogen response at temperatures equal to or less than those achieved at $10 \mathrm{~cm}$ soil depth in our FIELD and GHOUSE experiments. ${ }^{y}$ Field study; ${ }^{z}$ in vitro study.
}

\section{Conclusions}

Populations of culturable beneficial soil microbiota were not affected by field solarization, but soil biological activity was transiently reduced. Solarization resulted in seed mortality in both field and greenhouse, but the high (98\%) weed seed mortality measured in our greenhouse experiment came with a potential ecological tradeoff: populations of florescent pseudomonads and soil biological activity were reduced and remained suppressed following greenhouse solarization for the duration of our measurements. Available nitrogen increased during and after solarization in both the field experiment and the greenhouse experiment. Temperatures in these experiments were theoretically sufficient for the reduction of some regionally problematic soilborne pathogens. In a separate field experiment, solarization reduced soil biological activity following plastic removal, while the similar practice of tarping with black plastic did not, though differences between these mulching practices were not significant. Future research is needed to determine whether results from these experiments can be generalized over a broader range of soil and environmental conditions, to determine whether solarization in our region results in improved crop yields and is economically viable, and to explore the potential of solarization to contribute to plant pathogen control in the Northeast USA.

\section{Acknowledgements}

We would like to thank especially Stom Ohno for sharing his expertise and lab space; Helen Jiang, Missi Zhang, and Nayara Marangoni for sharing their lab space and answering myriad questions; and Liam Kenefic and Lucia Helder for their excellent work. Thanks also to Joseph Cannon, Thomas Molloy, Brad Libby, Avinash Rude, Ellen Mallory, Brian McGill, David Hiebeler, and our anonymous reviewers. Thanks to Zane Thistleford, Kaizad Patel, and Bruce Hoskins for fielding chemistry questions. Funding was provided by the Swarthmore College Summer Research Fellow Program, the Maine Food and Agriculture Center, the Maine Agricultural and Forest Experiment Station Analytical Laboratory, and University of Maine EPSCoR. This project was further supported by the USDA National Institute for Food and Agriculture, Hatch Project Number ME0-21606 through MAFES. This is MAFES publication number 3704. 


\section{References and Notes}

[1] Katan J, Greenberger H, Alon H, Grinstein A. Solar Heating by Polyethylene Mulching for the Control of Diseases Caused by Soilborne Pathogens. Phytopathology. 1976;(66):683-688.

[2] Horowitz M, Regev Y, Herzlinger G. Solarization for Weed Control. Weed Science. 1983;31(2):170-179. Available from: http: //www.jstor.org/stable/4043790.

[3] Cohen O, Rubin B. Non-Chemical Weed Management: Principles, Concepts and Technology. In: Soil Solarization and Weed Management. Cambridge: CABI; 2007. pp. 177-200. In: Upadhyaya MK, Blackshaw RE, editors. In: Upadhyaya MK, Blackshaw RE, editors.

[4] Katan J. Solar Heating (Solarization) of Soil for Control of Soilborne Pests. Annual Review of Phytopathology. 1981;19(1):211-236. doi:10.1146/annurev.py.19.090181.001235.

[5] McGovern RJ, McSorley R. Management of Bacterial and Fungal Plant Pathogens by Soil Solarization. In: Gamliel A, Katan J, editors. Soil Solarization: Theory and Practice. The American Phytopathological Society; 2012. pp. 53-62.

[6] Walters T, Pinkerton J. Soil Solarization: A Perspective from Cool Northern Regions. In: Gamliel A, Katan J, editors. Soil Solarization: Theory and Practice. The American Phytopathological Society; 2012. pp. 199-205.

[7] Kapulnik Y, Gamliel A. Combining Soil Solarization with Beneficial Microbial Agents. In: Gamliel A, Katan J, editors. Soil Solarization: Theory and Practice. The American Phytopathological Society; 2012. pp. 121-128.

[8] Chellemi D, Olson S, Mitchell D, Secker I, McSorley R. Adaptation of Soil Solarization to the Integrated Management of Soilborne Pests of Tomato under Humid Conditions. Phytopathology. 1997;10(3):250258. doi:10.1094/PHYTO.1997.87.3.250.

[9] Dahlquist R, Prather T, Stapleton J. Time and Temperature Requirements for Weed Seed Thermal Death. Weed Science. 2007;55:619625. doi:10.1614/WS-04-178.1.

[10] Marenco R, Lustosa D. Soil Solarization for Weed Control in Carrot. Pesquisa Agropecuária Brasileira. 2000;35:2025-2035. doi:10.1590/S0100-204X2000001000014.

[11] Egley GH. High-Temperature Effects on Germination and Survival of Weed Seeds in Soil. Weed Science. 1990;38(4/5):429-435. Available from: http://www.jstor.org/stable/4044899.

[12] Stapleton J, Dahlquist-Willard R, Achmon Y, Marshall M, Vandergheynst $J$, Simmons C. Advances in Biosolarization Technology to Improve Soil Health and Organic Control of Soilborne Pests. Organic agricuture research symposium; 2016. Available from: https://eorganic.info/sites/eorganic.info/files/u27/1.1.2Stapleton-Biosolarization-Final.pdf.

[13] Gallandt ER. How Can We Target the Weed Seedbank? Weed Science. 2006;54(3):588-596. Available from: http://www.jstor.org/ stable/4539433.

[14] Runia W. Soil Disinfestation by Soil Heating. In: Gamliel A, Katan J, editors. Soil Solarization: Theory and Practice. The American Phytopathological Society; 2012. pp. 23-31.

[15] Chen Y, Katan J, Gamliel A, Aviad T, Schnitzer M. Involvement of Soluble Organic Matter in Increased Plant Growth in Solarized Soils. Biology and Fertility of Soils. 2000;32:28-34. doi:10.1007/s003740000209.

[16] Khan M, Marwat K, Amin A, Khan A, Khan R, Khan DH, et al. Soil Solarization: An Organic Weed Management Approach in Cauliflower. Communications in Soil Science and Plant Analysis. 2012;43:18471860. doi:10.1080/00103624.2012.684822.

[17] Sofi TA, Tewari AK, Razdan VK, Koul VK. Long term effect of soil solarization on soil properties and cauliflower vigor. Phytoparasitica. 2013;42(1):1-11. doi:10.1007/s12600-013-0331-z.

[18] Öz H, Coskan A, Atilgan A. Determination of Effects of Various Plastic Covers and Biofumigation on Soil Temperature and Soil Nitrogen Form in Greenhouse Solarization: New Solarization Cover Material. Journal of Polymers and the Environment. 2016;Oz, H., and Coskan, A. and Atilgan, A.:370-377. doi:10.1007/s10924-016-0819-y.

[19] Gelsomino A, Cacco G. Compositional Shifts of Bacterial Groups in a Solarized and Amended Soil as Determined by Denaturing Gradient Gel Electrophoresis. Soil Biology and Biochemistry. 2006;38:91-102. doi:10.1016/j.soilbio.2005.04.021.
[20] Scopa A, Dumontet S. Soil Solarization: Effects on Soil Microbiological Parameters. Journal of Plant Nutrition. 2007;30:537-547. doi:10.1080/01904160701209212.

[21] Scopa A, Candido V, Dumontet S, Miccolis V. Greenhouse Solarization: Effects on Soil Microbiological Parameters and Agronomic Aspects. Scientia Horticulturae. 2008;116:98-103. doi:10.1016/j.scienta.2007.11.008.

[22] Katan J, Gamliel A. Mechanisms of pathogen and disease control and plant-growth improvement involved in soil solarization. In: Gamliel A, Katan J, editors. Soil Solarization: Theory and Practice. The American Phytopathological Society; 2012. pp. 23-31.

[23] Gullino M, Garibaldi A. Solarization under Greenhouse Conditions. In: Gamliel A, Katan J, editors. Soil Solarization: Theory and Practice. The American Phytopathological Society; 2012. pp. 187-191.

[24] Barakat R, Al-Masri M. Enhanced Soil Solarization against Fusarium oxysporum f. sp. lycopersici in the Uplands. International Journal of Agronomy. 2012;2012:1-7. doi:10.1155/2012/368654.

[25] Garibaldi A, Tamietti G. Attempts to Use Soil Solarization in Closed Glasshouses in Northern Italy for Controlling Corky Root of Tomato. Acta Horticulturae. 1983;(152):237-244. doi:10.17660/ActaHortic.1984.152.25.

[26] Stevens C, VA K, Wilson M, Brown J, Collins D. Use of Thermofilm-IR Single Layer and Double Layer Soil Solarization to Improve Solar Heating in a Cloudy Climate. Plasticulture. 1999;(118):20-34.

[27] Fortier JM. The Market Gardener. Vancouver, Canada: New Society Publishers; 2014.

[28] Standifer LC, Wilson PW, Porche-Sorbet R. Effects of Solarization on Soil Weed Seed Populations. Weed Science. 1984;32(5):569-573. doi:10.1017/S0043174500059580.

[29] Station Details: Bangor International Airport. Silver Spring, MD, USA: National Oceanic and Atmospheric Administration; 2018. Available from: https://www.ncdc.noaa.gov/cdo-web/datasets/GHCND/ stations/GHCND:USW00014606/detail.

[30] Data Tools: 1981-2010 Normals. Silver Spring, MD, USA: NOAA National Centers for Environmental Information; 2018. Available from: https://www.ncdc.noaa.gov/cdo-web/datatools/normals.

[31] Meng QM, Yin J, Rosenzweig N, Douches D, Hao J. Culture-Based Assessment of Microbial Communities in Soil Suppressive to Potato Common Scab. Plant Disease. 2012;96:712-717. doi:10.1094/PDIS05-11-0441.

[32] Tarnawski S, Hamelin J, Locatelli L, Aragno M, Fromin N. Examination of Gould's Modified S1 (mS1) Selective Medium and Angle's Non-selective Medium for Describing the Diversity of Pseudomonas spp. in Soil and Root Environments. FEMS Microbiology Ecology. 2003;45(2):97-104. doi:10.1016/S0168-6496(03)00130-2.

[33] Franzluebbers A. Should soil testing services measure soil biological activity? Agricultural \& Environmental Letters. 2016;1(1):1-5. doi:10.2134/ael2015.11.0009.

[34] Crawley MJ. The R Book. John Wiley \& Sons, Ltd; 2013. Available from: https://doi.org/10.1002\%2F9781118448908. doi:10.1002/9781118448908.

[35] Gotelli N, Ellison A. A primer of ecological statistics. USA: Sinauer Associates; 2004.

[36] R Core Team. R: A Language and Environment for Statistical Computing. Available from: https://www.R-project.org/.

[37] McGarigal K. Biostats R. Available from: https://www.umass.edu/ landeco/teaching/ecodata/labs/ecodata labs.html.

[38] Rizzo M, Szekely G. Energy: E-Statistics: Multivariate Inference Via the Energy of Data. Available from: https://www.umass.edu/landeco/ teaching/ecodata/labs/ecodata labs.html.

[39] Oksanen MFRKPLDMPRMRBOGLSPSMHHSESHW F Guillaume Blanchet. Vegan: Community Ecology Package. Available from: http://cran.r-project.org/package=vegan.

[40] Hothorn T, Bretz F, Westfall P. Simultaneous Inference in General Parametric Models. Biometrical Journal. 2008;50:346-63. doi:10.1002/bimj.200810425.

[41] Giraudoux P. Pgirmess: data analysis in ecology.

[42] Warnes GR, Bolker B, Gorjanc G, Grothendieck G, Korosec A, Lumley $\mathrm{T}$, et al. gdata: Various R Programming Tools for Data Manipulation. $R$ package version 2.18.0. Available from: https://CRAN.Rproject.org/package $=$ gdata.

[43] Soil Survey. National Resources Conservation Service Web Soil 
Survey; 2018. Available from: https://websoilsurvey.sc.egov.usda. gov/App/WebSoilSurvey.aspx.

[44] Wall D. Making Soil Biodiversity Matter for Agriculture: Ecosystem Services and Challenges. In: Cheeke T, Coleman D, Wall D, editors. Microbial Ecology in Sustainable Agroecosystems. CRC Press; 2013.

[45] Baker B, Mohler C. Weed Management by Upstate New York Organic Farmers: Strategies, Techniques and Research Priorities. Renewable Agriculture and Food Systems. 2014;30:1-10. doi:10.1017/S1742170514000192.

[46] Santoyo G, Orozco-Mosqueda M, Melappa G. Mechanisms of Biocontrol and Plant Growth-Promoting Activity in Soil Bacterial Species of Bacillus and Pseudomonas: A review. Biocontrol Science and Technology. 2012:22:855-872. doi:10.1080/09583157.2012.694413.

[47] Kloepper J, Ryu CM, Zhang S. Induced Systemic Resistance and Promotion of Plant Growth by Bacillus spp. Phytopathology. 2004;(94):1259-1266. doi:10.1094/PHYTO.2004.94.11.1259.

[48] Mazurier S, Corberand T, Lemanceau P, Raaijmakers J. Phenazine Antibiotics Produced by Fluorescent Pseudomonads Contribute to Natural Soil Suppressiveness to Fusarium wilt. The ISME Journal. 2009;3:977-991. doi:10.1038/ismej.2009.33.

[49] Baril E, Coroller L, Couvert O, El Jabri M, Leguerinel I, Postollec $\mathrm{F}$, et al. Sporulation Boundaries and Spore Formation Kinetics of Bacillus spp. as a Function of Temperature, $\mathrm{pH}$ and $\mathrm{a}(w)$. Food Microbiology. 2012;32:79-86. doi:10.1016/j.fm.2012.04.011.

[50] Rubin B. Soil solarization as a tool for weed management. In: Gamliel A, Katan J, editors. Soil Solarization: Theory and Practice. American Phytopathological Society; 2012. pp. 71-76.

[51] Baskin C, Baskin J. Seeds: Ecology, Biogeography, and Evolution of Dormancy and Germination; 1998. doi:10.1016/B978-0-12-0802609.X5000-3.

[52] Brown B, Gallandt E. To Each their Own: Case Studies of Four Successful, Small-Scale Organic Vegetable Farmers with Distinct Weed Management Strategies. Renewable Agriculture and Food Systems. 2017;pp. 1-7. doi:10.1017/S1742170517000576.

[53] Achmon Y, Fernández-Bayo J, Hernandez K, McCurry D, Harrold D, su J, et al. Weed Seed Inactivation in Soil Mesocosms Via Biosolarization with Mature Compost and Tomato Processing Waste Amendments. Pest Management Science. 2016;73. doi:10.1002/ps.4354.

[54] Díaz-Hernández S, Gallo-Llobet L, Domínguez-Correa P, Rodriguez A. Effect of Repeated Cycles of Soil Solarization and Biosolarization on Corky Root, Weeds and Fruit Yield in Screen-House Tomatoes under Subtropical Climate Conditions in the Canary Islands. Crop Protection. 2017;94:20-27. doi:10.1016/j.cropro.2016.12.010.

[55] Özyılmaz U, Benlioglu K, Yildiz A, Benlioglu S. Effects of Soil Amendments Combined with Solarization on the Soil Microbial Community in Strawberry Cultivation Using Quantitative Real-Time PCR. Phytoparasitica. 2016;pp. 661-680. doi:10.1007/s12600-016-0552-z.

[56] Kanaan H, Minz D, Medina S, Krasnovsky A, Raviv M. The Interdependent Effects of Solar Disinfestation and Compost Maturity Level on Soil Microbial Activity. Phytoparasitica. 2015;44:55-64. doi:10.1007/s12600-015-0501-2.

[57] Seong KY, Höfte M, Boelens J, Verstraete W. Growth, Survival, and
Root Colonization of Plant Growth Beneficial Pseudomonas fluorescens ANP15 and Pseudomonas aeruginosa 7NSK2 at Different Temperatures. Soil Biology and Biochemistry. 1991;23(5):423-428. doi:10.1016/0038-0717(91)90004-4.

[58] Gamliel A, Katan J. Involvement of Fluorescent Pseudomonads and other Microorganisms in Increased Growth-Response of Plants in Solarized Soils. Soil Biology and Biochemistry. 1991;(81):494-502. Available from: https://www.apsnet.org/publications/phytopathology/ backissues/Documents/1991Articles/Phyto81n05_494.PDF.

[59] Mahrer Y, Shilo E. Physical Principles of Solar Heating of Soils. In: Gamliel A, Katan J, editors. Soil solarization: theory and practice. American Phytopathological Society; 2012. pp. 147-152.

[60] Bihan B, Camporota P, Soulas M, Salerno M, Perrin R. Evaluation of Soil Solar Heating for Control of Damping-off Fungi in Two Forest Nurseries in France. Biology and Fertility of Soils. 1997;25:189-195. doi:10.1007/s003740050302.

[61] Vakalounakis D, Malathrakis N. A Cucumber Disease Caused by Alternaria alternata and its Control. Journal of Phytopathology 1988:121:325-336. doi:10.1111/j.1439-0434.1988.tb00976.x.

[62] Abu-Gharbieh WI, Saleh H, Abu-Blan H. Use of Black Plastic for Soil Solarization and Post-plant Mulching. Amman, Jordan: Plant Protection Depatment, University of Jordan; 1988. Available from: http://www.fao.org/docrep/t0455e/T0455E0j.htm.

[63] Tsror L, Erlich O, Mordechai Lebiush S, Hazanovsky M, Zig U, Sławiak M, et al. Assessment of Recent Outbreaks of Dickeya sp. (syn. Erwinia chrysanthemi) Slow Wilt in Potato Crops in Israel. European Journal of Plant Pathology. 2008;123:311-320. doi:10.1007/s10658008-9368-0.

[64] Smadja B, Latour X, Trigui S, Burini J, Chevalier S, Orange N. Thermodependence of Growth and Enzymatic Activities Implicated in Pathogenicity of Two Erwinia carotovora Subspecies (Pectobacterium spp.). Canadian Journal of Microbiology. 2004;50:19-27. doi:10.1139/w03-099.

[65] Pinkerton JN, Ivors K, Reeser P, Bristow P, Windom G. The Use of Soil Solarization for the Management of Soilborne Plant Pathogens in Strawberry and Red Raspberry Production. Plant Disease. 2002:86:645-651. doi:10.1094/PDIS.2002.86.6.645.

[66] Drenth A, Janssen E, Govers F. Formation and Survival of Oospores of Phytophthora infestans. Plant Pathology. 2007;44:86-94. doi:10.1111/j.1365-3059.1995.tb02719.x.

[67] Chellemi D. Effects of Soil Solarization and Fumigation on Survival of Soilborne Pathogens of Tomato in Northern Florida. Plant Disease. 1994;78:1167-1172. doi:10.1094/PD-78-1167.

[68] Cartia G, Asero C. The Role of Temperature Regarding Sclerotinia sclerotiorum in the Soil. Acta Horticulturae. 1994;366:323-330. doi:10.17660/ActaHortic.1994.366.40.

[69] Pullman G, DeVay J, Garber R, Weinhold A. Soil Solarization: Effects on Verticillium Wilt of Cotton and Soilborne Populations of Verticillium dahliae, Pythium spp., Rhizoctonia solani, and Thielaviopsis basicola. Phytopathology. 1981;71:954-959. doi:10.1094/Phyto-71-954.

[70] Smith $\mathrm{H}$. The Morphology of Verticillium albo-atrum, $V$. dahliae, and $V$. tricorpus. New Zealand Journal of Agricultural Research. 1965:8:450-478. doi:10.1080/00288233.1965.10419889. 


\section{Appendix}

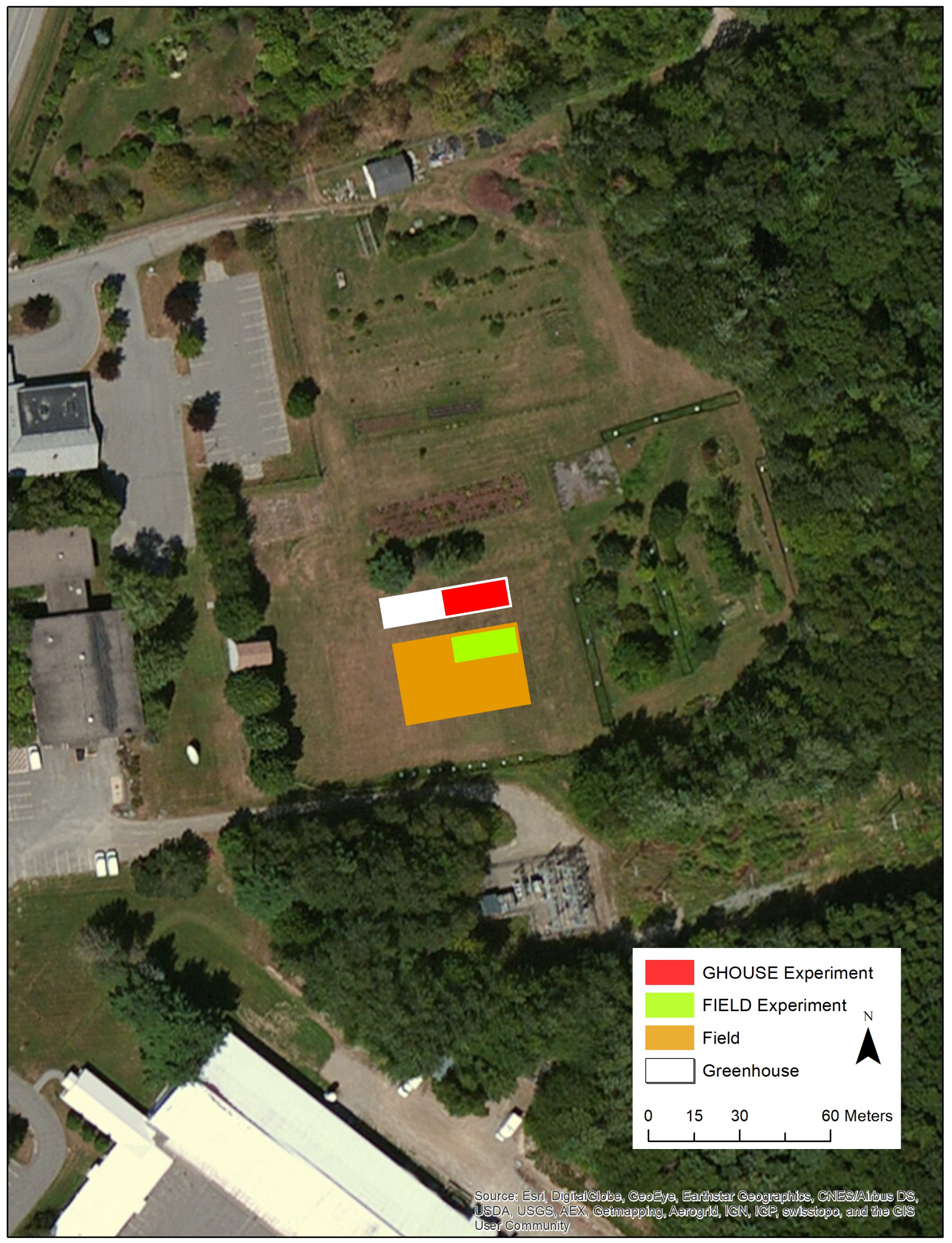

Figure A1. Aerial view showing FIELD and GHOUSE experiment locations. 


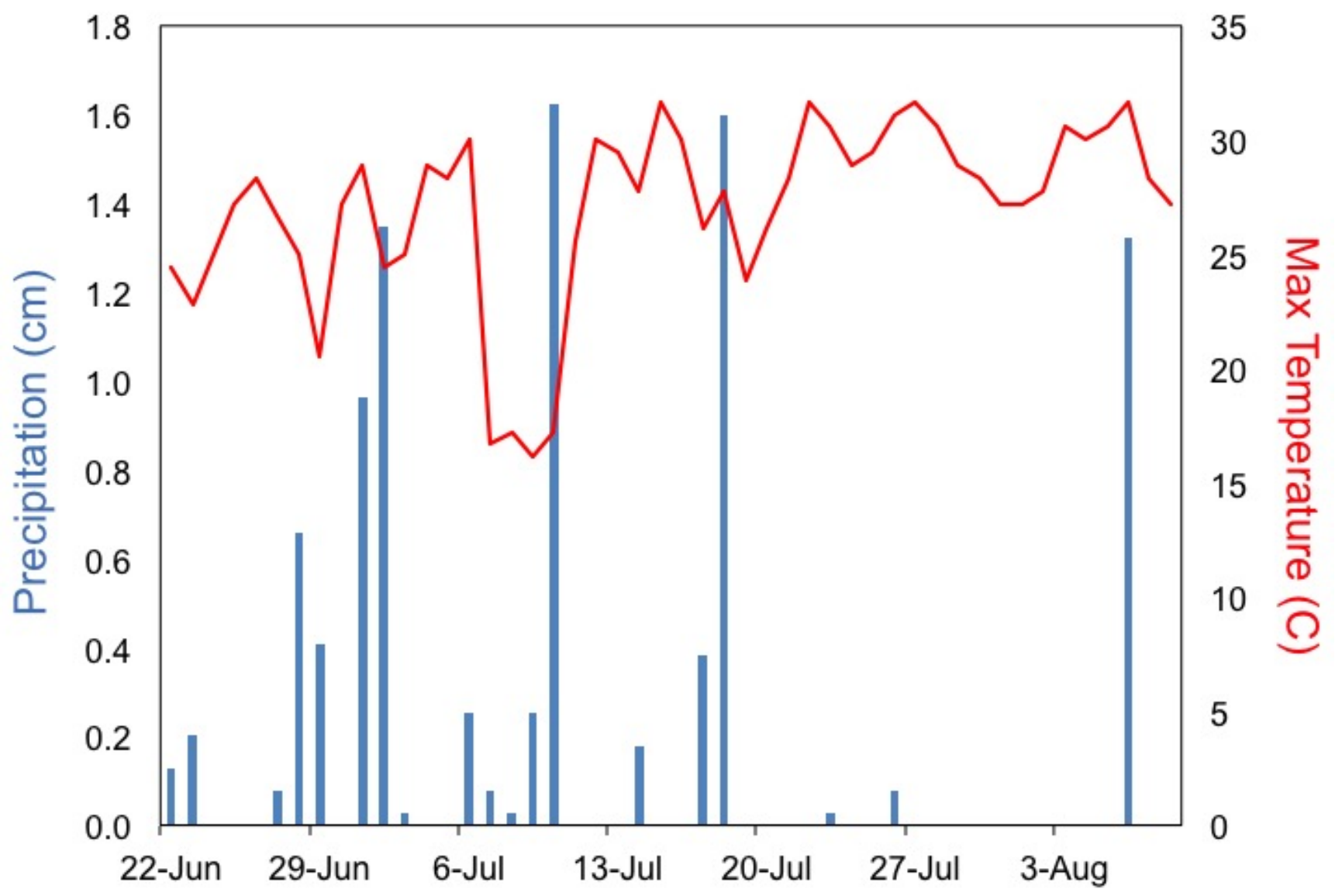

Figure A2. Daily precipitation (blue bars) and maximum air temperature (red line) during FIELD and GHOUSE experiments.

Table A1. ANOVA tables for weed seed viability in FIELD and GHOUSE experiments.

\begin{tabular}{llcccccccc}
\hline & & \multicolumn{3}{c}{ FIELD } & & \multicolumn{3}{c}{ GHOUSE } \\
\cline { 3 - 5 } \cline { 7 - 9 } & & df & $\mathbf{F}$ & $\boldsymbol{p}$ & & df & F & $\boldsymbol{p}$ \\
\hline \multirow{2}{*}{ Termination } & Treatment & 1 & 5.85 & $0.03^{*}$ & & 1 & 122.73 & $<0.01^{*}$ \\
& Seed Sp. & 2 & 4.81 & $0.02^{*}$ & & 2 & 1.60 & 0.24 \\
& T $\times$ Sp. & 2 & 0.20 & 0.82 & & 2 & 3.57 & 0.07 \\
& Residuals & 18 & & & & 18 & & \\
\hline
\end{tabular}

Models were constructed to test the effects of solarization treatment and seed species on weed seed viability after four weeks of solarization. $P$-values significant at the $\alpha=0.05$ level are shown with an asterisk $\left(^{*}\right)$. Due to non-normality of residuals in the GHOUSE model, simulated $p$-values calculated via permutation test are presented. 